\title{
O Novo Nascimento por obra do Espírito: Jo 3,1-12 à luz da profecia de Ez 36,24-28
}

Orientadora: Maria de Lourdes Corrêa Lima

Mestranda: Rani dos Santos Jaber

Área de Concentração: Teologia Bíblica

Linha de Pesquisa: Análise e Interpretação de Textos do Antigo e Novo Testamento

O Evangelho segundo João desperta grande interesse pelas alusões, em preferência às citações, que faz do Antigo Testamento para anunciar a Boa Nova de Jesus. Localizada no primeiro momento em que, neste Evangelho, Jesus se dirige aos judeus (cf. Jo 2,13-3,36), a perícope de Jo 3,1-12 é a primeira grande seção do diálogo com Nicodemos, um fariseu e um principal dentre os judeus, que, pelas formas plurais ali empregadas, sabe-se estar também representando seus pares, neste diálogo que tocará em pontos centrais a estes. $\mathrm{O}$ anúncio, feito por Jesus, de um novo nascimento que, progressivamente, se apresenta como sendo "do alto", "de água e espírito", "do Espírito", é incompreendido por Nicodemos. A repreensão que lhe é dirigida em seguida, por ser "mestre de Israel" e desconhecê-lo (cf. Jo 3,9-10), indica que na base do anúncio feito está algum texto das Escrituras de Israel. A pesquisa realizada encontrou na profecia de Ez 36,24-28 consideráveis correspondências textuais com Jo 3,1-12. A dissertação se propõe a aprofundar a compreensão de Jo 3,1-12 a partir da análise exegética desta perícope, situando-a em seu contexto amplo e imediato, da análise exegética de Ez 36,24-28 e da análise das relações intertextuais, segundo os critérios de Markl, dos dois textos citados.

Palavras-chave: Nicodemos. Água. Espírito. 